\title{
Test ban 'within reach', say negotiators
}

Paris. After five weeks of tense negotiation, ending last Friday, a treaty banning all nuclear tests seems likely to be sent for approval to the United Nations General Assembly in September. But backroom negotiations in individual countries over the next month will be critical in determining whether the treaty obtains the backing needed to allow its full implementation.

The Conference on Disarmament, which is negotiating the Comprehensive Test Ban Treaty (CTBT) in Geneva, had fixed a deadline of 28 June for drafting a final text, the latest date possible if the text is to go before the United Nations in September.

The failure of the conference to agree on the text last week has been interpreted by some as a failure of the negotiations themselves. But others point out that the conference succeeded in its aim of completing negotiations on the main thorny issues.

Indeed, the text submitted by Jaap Ramaker, the Dutch diplomat who is chairing the conference, on the afternoon of the deadline is expected to be almost identical to the text that will go to the UN, says Rebecca Johnston, of Disarmament Intelligence Review.

Only a few weeks ago, the text contained thousands of sections that had still to be agreed. But many contentious issues have since been settled. China has relinquished its demand to be allowed to carry out peaceful nuclear explosions, and all five nuclear weapons states - known as the P5 - have also agreed a ban on low-yield nuclear explosions.

Many delegates had hoped to reach an agreement in principle on the text before the deadline expired. But no formal agreement could have been reached before the text had been reviewed by the government of each country. A further delaying factor is that the outcome of Russia's presidential election will not be known until this week.

The next few weeks will see further intense discussions between government representatives before the last round of negotiations opens on 29 July. Observers are optimistic that no countries will demand major changes to the text, which would end all prospects of having a treaty signed in September. The leaders of the G7 countries reaffirmed their commitment to signing the treaty by this date at a meeting in Lyons, France, last weekend.

The major sticking-points in the negotiations are the conditions under which the treaty would enter into force. The United Kingdom, Pakistan and Russia have insisted that the treaty should take effect only if it is ratified by at least the five nuclear weapons states and the three threshold weapons states, India, Pakistan and Israel - the socalled 'group of eight'.

This has become a Catch-22 situation.
India says it will not sign because the treaty does not provide sufficient commitment to nuclear disarmament, although it says that it will not block agreement by other states. But by making the treaty's entry into force dependent on India's signature, the conference risks scuttling the entire exercise.

Some observers are cautiously optimistic that the discussions over the next four weeks could result in a softening of the conditions on entry into force. The United States said last week that it was willing to be "flexible" on the issue. This has raised hopes that the US administration might exert pressure on the United Kingdom, Russia

and Pakistan to relax their demands.

Eliminating the requirement that the treaty's entry into force should depend on a signature by the group of eight would remove the biggest obstacle to reaching agreement.

Meanwhile, the final text proposed last week also includes a possible way out of the dilemma. Although it insists that the treaty be ratified by at least 45 countries - including the group of eight - before it could enter into force, it says that if this condition is not met within three years, a conference would be convened to find a solution.

Declan Butler

\section{Japan plans for more technicians}

Tokyo. In addition to promising major increases in funding, Japan's new fiveyear plan for science and technology, announced last week by the Council of Science and Technology, could revolutionize employment practices in government research organizations, according to scientists leading the reform of Japan's public sector research system.

The plan was drawn up by the council, Japan's highest policy-making body for science and technology, as required by a new law passed last November. In addition to setting an ambitious target for total government expenditure on science and technology of $¥ 17,000$ billion (US $\$ 160$ billion) over the next five years, it calls for the ratio of technical support staff to researchers to be increased to 1:2 for national universities and 1:1 for national research institutes, far above current levels.

Since the late 1970s, Japan's universities have suffered from a steadily growing shortage of technicians, due the government's policy of cutting down on the number of government employees including university staff. The new policy aims to reverse that trend.

According to a spokesman for the Science and Technology Agency, which helped to draft the plan, this will probably be achieved by hiring part-time or contract employees, circumventing rules that traditionally give lifetime employment to all government employees, including university researchers and technicians. Scientists say that such a move could set a precedent for more flexible employment practices throughout the public-sector research system.

Michio Oishi, director of the Ministry of International Trade and Industry's National Institute for Bioscience and Human Technology, says that this is "the most important plan in 20-30 years".
He adds that among the most revolutionary aspects are the plan's support for contract employment for government and university researchers.

Some institutions - including Oishi's own - are considering introducing systems under which researchers will be granted permanent employment only after their performance has been evaluated over a provisional period of several years. But there is at present no legal basis for the provisional hiring of government employees.

Akito Arima, president of the Institute for Physical and Chemical Research, and chairman of a subcommittee within the University Council that is considering the issue of limited-term employment for university researchers, says that the government is now considering legislation to put such hiring practices on a more secure legal footing.

But although there is general support for more flexible employment practices among government scientists, widespread adoption of such systems will require effective evaluation of individual researchers' performance, says Oishi.

Many observers point out that the Japanese government frequently produces science policy statements that are full of good intentions but are generally not implemented in full. This time, however, despite opposition from the Ministry of Finance, there appears to be a set budget for science and technology which will help smooth the introduction of the promised reforms.

But money may yet prove to be the biggest obstacle to implementation of the plan. With the government facing a huge deficit, the finance ministry's view that the forecast expenditure cannot be afforded may yet still prevail, if political support for the plans should falter.

Stephen Barker 